\title{
MEETING FOR TRANSFORMATION
}

\section{A Locality for Ritual Activities During the Early Neolithic Funnel Beaker Culture in Central Sweden}

\author{
Lars Larsson \& \\ Sven-Gunnar Broström
}

The former island of Södertörn, just south of Stockholm, was intensively settled during the Early Neolithic. For more than twenty years a field at Stensborg, Grödinge parish, was surveyed for surface finds. Most numerous among the various artefact categories were axes, with stone axes of different shapes showing that they had been intentionally fragmented. Fragments of pointed-butted and thin-butted flint axes were also found, all of them changed by intensive heat. Just as the flint axes indicate contact with southern Scandinavia, slate objects demonstrate the existence of networks extending to northern Sweden.

During the Early Neolithic the site was a slope situated in the innermost part of a bay, delimited by the shoreline on one side and a ridge on the opposite side. Two small but pronounced ravines of streams also form part of the natural boundary of the site.

During excavation of the field several small pits were found that were filled with fragments of axes, pottery and other objects, along with a considerable amount of carbonized seed. Most of the finds have indications of destruction, either directly or by the use of fire. The field seems to have been used as a place for assemblies, where rituals were an important part of the activities. The Stensborg site seems to represent yet another kind of natural enclosure involving ritual activities during the Early Neolithic. This presentation is part of a project in progress.

Keywords: Early Neolithic, central Sweden, stone and flint axes, ritual deposition, destruction of objects, fire 


\section{INTRODUCTION}

Most societies form or identify certain spaces delimited from the physical as well as the social environment in order to perform activities of special character. The best-known examples in southern Scandinavia dating to the time of the Funnel Beaker culture are the causewayed enclosures and the areas outside megalithic tombs. Such spaces, located at a physical and mental distance from everyday activities, have been regarded as forming links between this world and a metaphysical one, where transformations are achieved by depositing objects directly or in a manner that involves transformation through fragmentation and burning. These spaces are sites for destruction, but at the same time they represent a focus for life-giving. Axes and other objects have been interpreted as passing through a ritual death in order to attain another life.

Recent excavations in central Sweden seem to indicate that the introduction of farming and pastoralism took place just a few generations later than in the southernmost part of the country. With a few exceptions, the material culture of central Sweden is similar to that of the southern part. However, the farming societies lasted only a few centuries. In about $3300 \mathrm{cal}$. $\mathrm{BC}$ a change occurred: farming and pastoralism almost disappeared (Malmer 2003; Hallgren 2008). Fishing and hunting, which had been of importance earlier as well, became totally dominant in the economy (Edenmo et al. 1997; Carlsson I998). The links to the south, which had been important during the early Sub-Boreal, almost disappeared and were replaced by other networks. However, the change does not seem to have been dramatic: rather, it was a process that lasted generations.

Thanks to a number of excavations connected with exploitation of the region in the neighbourhood of Stockholm, our information about the period in question has improved considerably so that we now have a number of sites that vary in size and location (Hallgren 2008). The marked monumentality characteristic of southern Scandinavia, represented by the earthen long barrows and megalithic tombs such as dolmens, is indicated by just a couple of uncertain features. Other evidence of ritual activities, such as deposition of flint axes, common further to the south, is present. As in southern Scandinavia, rituals were conducted at or close to the settlement sites and took the form of deposition of pottery in wetlands (Hallgren et al. 1997) or intentional destruction of flint and stone axes. However, one site has produced exceptional evidence of activities with a ritual connection. 


\section{FINDS AT STENSBORG}

For almost twenty years one of the authors walked the fields on the northeastern slope of a pronounced valley at Stensborg, located about $30 \mathrm{~km}$ south of Stockholm (figure $\mathrm{r}$ ). He found tools in a field measuring $75 \times 50 \mathrm{~m}$, sloping from about $47 \mathrm{~m}$ down to $37 \mathrm{~m}$ above sea level. The field was delimited by the pronounced edge of a much steeper slope extending down to the valley bottom at about $27 \mathrm{~m}$ (figure 2). A small ridge to the east delimits the field. Artefacts were also found in fields on the other side and to the east of the ridge. Despite the density of finds, unusual for central Sweden, the positions of all 3400 objects were recorded using the field demarcation lines (Broström I996).

A special trend in the find material is its fragmentary condition. The majority of finds are pieces of polished stone axes made of greenstone. However, a considerable number of fragments are of a size that makes it impossible to determine the axe type. Based on necks and cutting

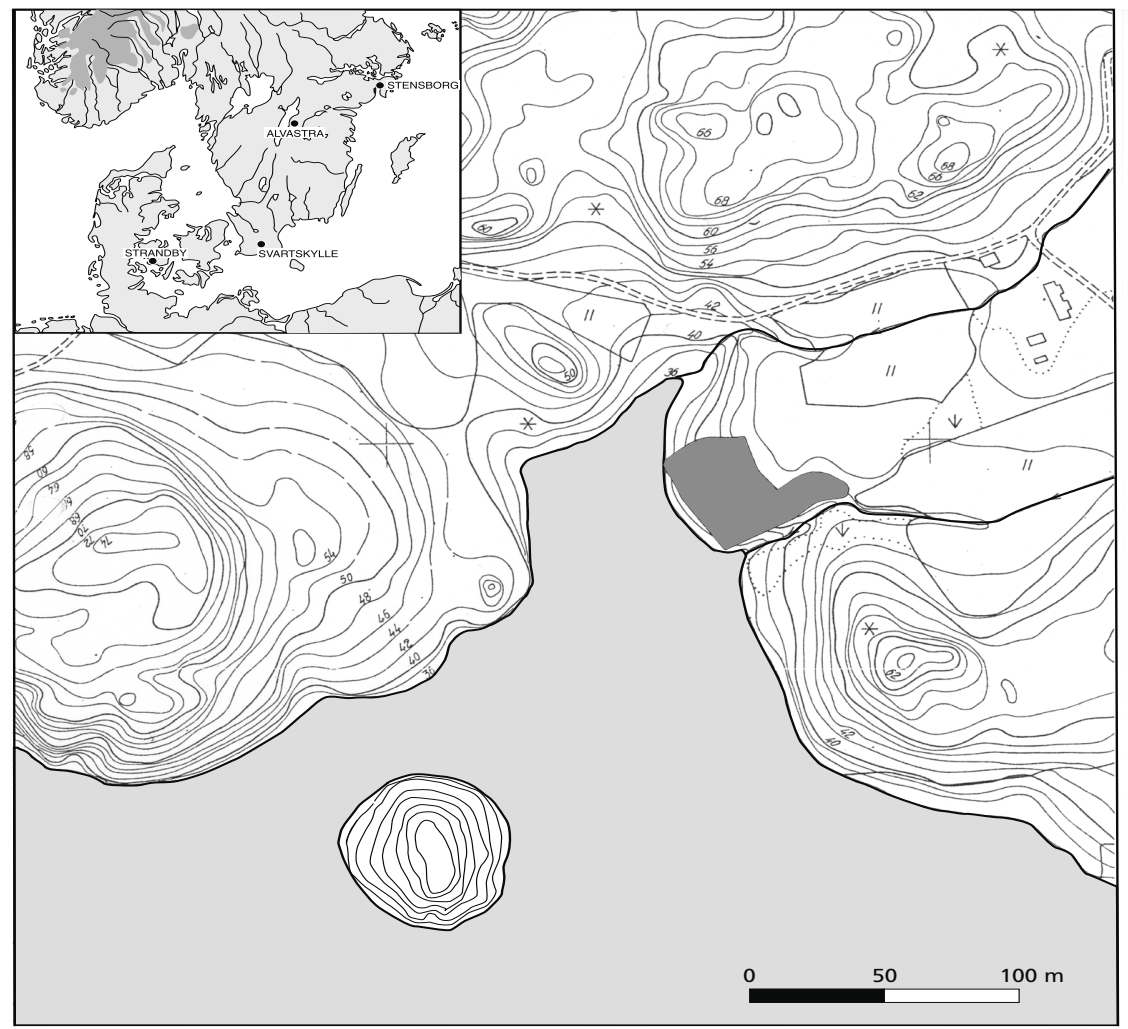

Figure I. The location of the site Stensborg during the Early Neolithic. The small map shows sites mentioned in the article. 


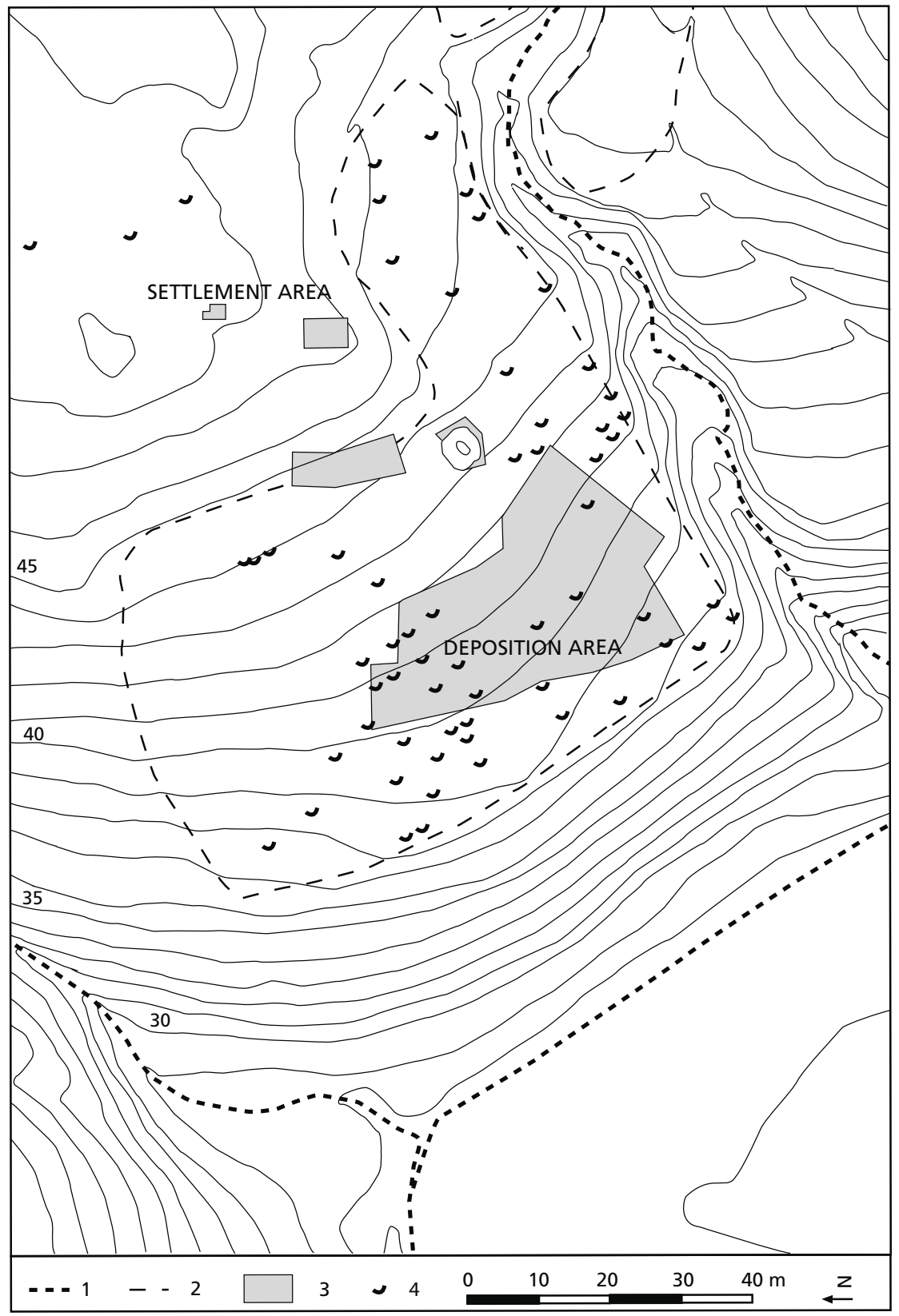

Figure 2. Plan of the site with one metre contours above present sea level. At the centre is the field with the large number of surface finds. The sea level at the time of the late Early Neolithic was about $35 \mathrm{~m}$ above present sea level. To the left and right are the outlets of two small brooks that form deep ravines. Legend: I) brook; 2) field enclosure; 3 ) area where the topsoil has been removed; 4) distribution of surface finds of stone axes with hollowed cutting edges. 
edges, more than fifty axes belong to the thin-butted axe type (Nielsen I978:72ff) (figure 3:I, 3:6 \& 4:3). Even more common is the type of axe with an oval or pointed-oval cross-section (figure $4: 4$ ).

The thin-butted examples correspond to the most common types made in flint in southern Scandinavia. The other type has a strong resemblance to the different types of more or less point-butted flint axes from the same area (Nielsen I978:65ff). There are just a small number of fragments proving that thin-bladed stone axes were also in circulation. More common is the stone axe with a hollowed cutting edge and with a rather thick neck (figure 3:5). The majority of these are made of a much harder mineral than most of the other axes, mainly porphyrite. They are in an especially fragmentary state, which makes it most problematic to calculate the original number of intact axes.

In most cases the axe body has been divided in two or more parts, most commonly with a breakage transverse to the long axis (figure 4:3). However, the axes with a hollowed cutting edge have cracked into a larger number of more or less quadratic pieces (figure 3:5) due to the harder material used, which has fragmented in a different way. This is the same kind of fragmentation as that observed for a small number of thin-butted axes made from harder stone (figure 3:6). A number of edges show minor evidence of use or none at all (figure 3:I \& 3:5). By contrast, a number of edges have deliberately been destroyed by hitting them against a hard material (figure $3: 6 \& 4: 3$ ). A small number of fragments show traces of intense heat, although such traces can be difficult to identify on stone objects (figure 4:4). The collection also includes fragmented stone axe performs (figure 4:I).

The collection also includes a small number of fragments of battleaxes that had a markedly curved shape with ridges, imitating copper axes from Continental Europe (figure 3:7) (Hallgren 2008:215ff).

More than five hundred pieces of flint show obvious traces of contact with fire, indicated by their white colour and by a fragmentation pattern typical of a special kind of contact with heat. The axes had been destroyed by fire, but not by placing them directly in a hearth. In that case the axes would have fragmented into tiny splinters. From experiments with heating of flint axes, it is clear that the Stensborg axes had initially been heat-treated and later placed on a bed of charcoal in a fire (Larsson 2004). By this procedure the axes changed colour, but if handled well they continued to keep their form. However, the multiple cracks that appeared made them difficult to handle and easy to break into pieces. Among the fragments, both thin-butted and point-butted axes can be identified (figure 3:2-3:4), with the former in the majority. The number of axes is difficult to estimate because of their fragmentary 

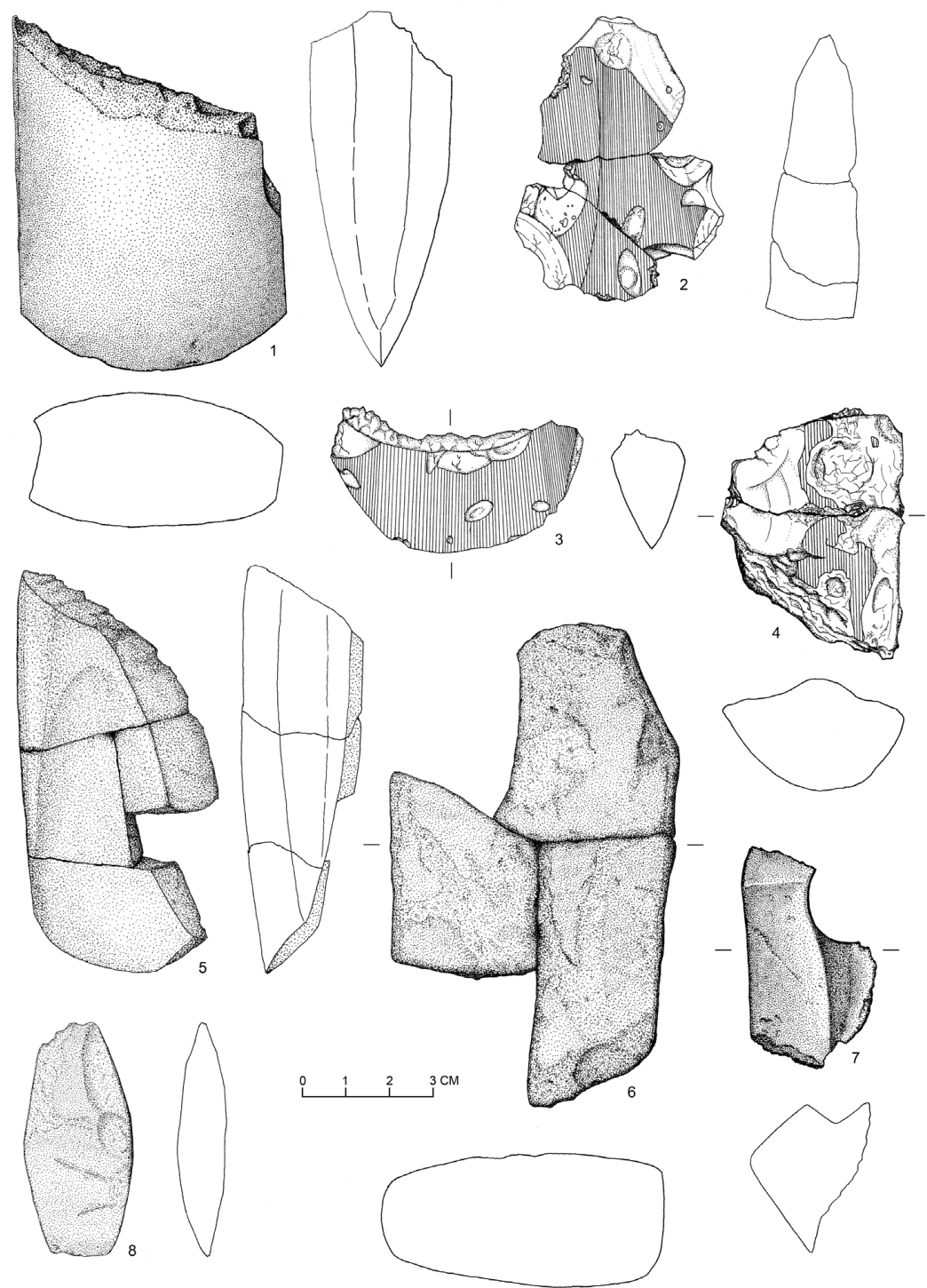

Figure 3. Axes from the site of Stensborg. I) Blade fragment of a thin-butted stone axe; 2) fragment of a point-butted flint axe; 3) blade fragment of a thin-butted flint axe; 4) fragments of a point-butted flint axe; 5) fragments of a stone axe with hollowed cutting edge; 6) fragments of a thin-butted stone axe; 7) fragment of a stone battle-axe; 8) stone chisel. Drawing by Krister Kam Tayanin.

state. Considering the size of some fragments, some must originate from very large axes with a length of $30 \mathrm{~cm}$ or more. Some well-preserved edge fragments without use-wear indicate that the axes might have been unused at the time they were fragmented. A small number of fragments of 
thin-butted axes show an unpolished surface, indicating that the axes had been transported to the area in an unpolished state.

Some blade fragments and flake scrapers of flint have been treated in the same way as the axes. The surface finds also include a number of knapping stones and several hundred fragments of polishing stones as well as grinding querns of the saddle type.

Several hundred pottery sherds were found (figure 5:3-5:6 \& $5: 8-$ $5: \mathrm{II})$. The number is exceptional considering that pottery easily crumbles on the surface, especially because of the weather conditions, with harsh winters. The pottery must have been found immediately after it had been brought to the surface by ploughing. A considerable proportion of the sherds are decorated with cord, whipped cord impressions and stamps. According to the type of decoration, the intensity of decoration and the profiles of the vessels, the pottery belongs to a late stage of the Early Funnel Beaker culture (Hallgren 2008:I35ff).

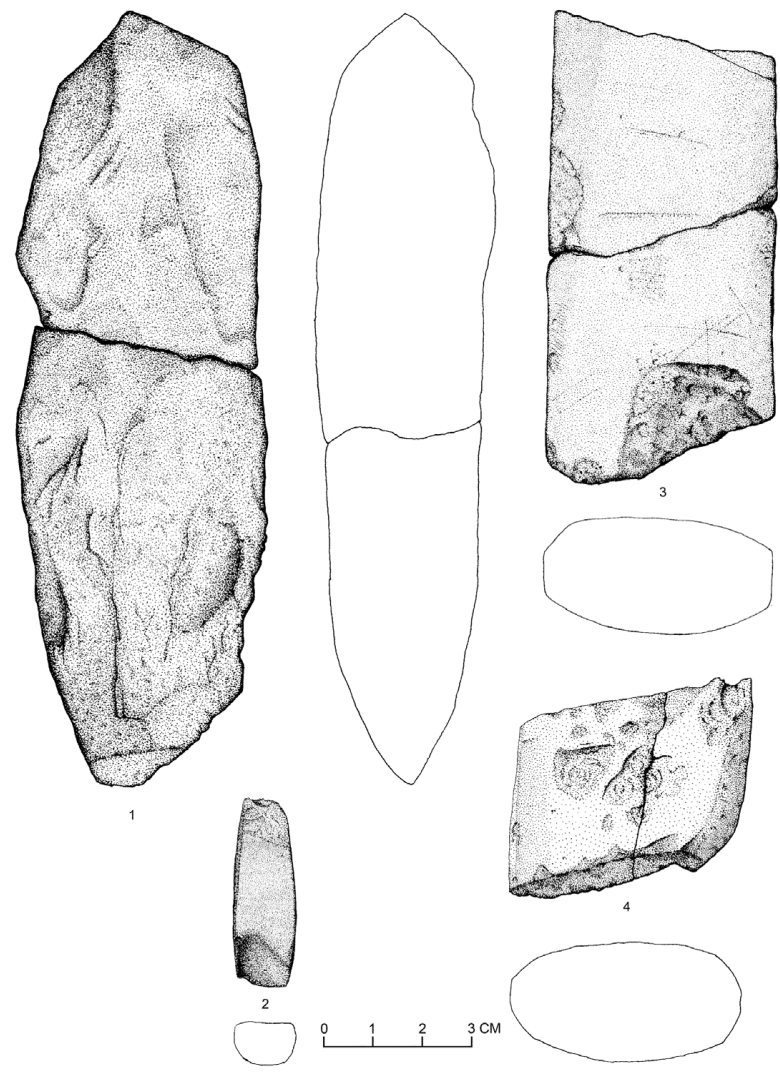

Figure 4. Finds from Stensborg. I) Preform of a stone axe; 2) stone chisel; 3-4) fragments of thin-butted stone axes. Drawing by Krister Kam Tayanin. 


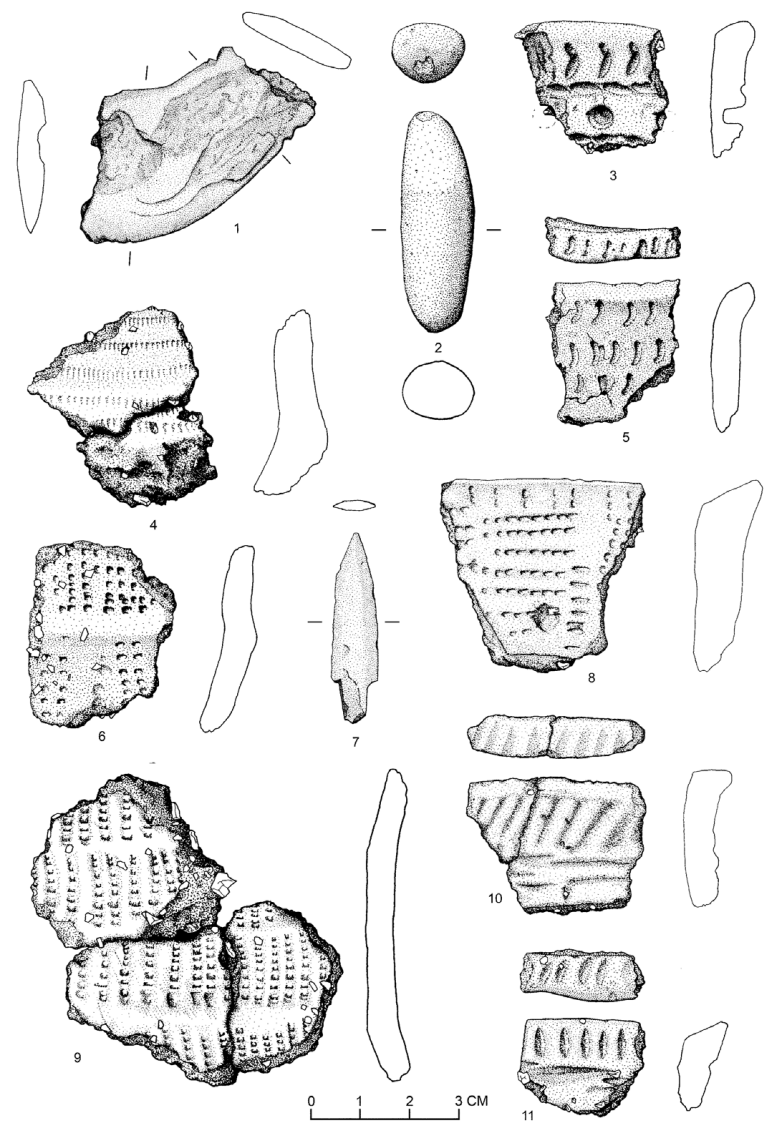

Figure 5. Finds from Stensborg. I) Fragment of a slate knife; 2) stone shaped like a phallus; $3-6,8-$ II) fragments of funnel beakers; 7) tanged slate arrowhead. Drawing by Krister Kam Tayanin.

The surface finds also included a fragmented, single-edged, curved slate knife and slate arrowheads from northern Sweden (Taffinder I998:99ff) (figure 5:I \& 5:7).

Objects from other periods are few. A small number of round-butted stone axes might belong to the Mesolithic, as they were found in the highest part of the site. A small number of objects including an arrowhead with a concave base date to the Late Neolithic.

\section{ENCLOSED SPACES}

The composition and state of the surface finds make the site exceptional. The use of fire and the fragmentation indicate a similarity to finds from sites such as causewayed enclosures. During the last decades a number 
of causewayed enclosures have been identified in Denmark, dating to the late Early Neolithic and the early part of the Middle Neolithic Funnel Beaker culture (3400-3200 BC) (Andersen 1997). They have been named Sarup enclosures after the location where such a structure was first recognised. More than twenty-five have been identified in Denmark (Jensen 200I:563). So far, just one has been found in southern Sweden (Larsson 1982). Because of the palisades and rows of pits, this kind of structure is easy to identify. Like most of the continental examples, enclosures of this kind have been interpreted as places for assemblies, where the finds and features include evidence of ritual practices that involved intentional damage by fire and deposition of special parts of the material culture (Andersen I997). There is evidence of similar activities, although usually less intensive, in connection to megalithic tombs (Larsson 2004).

Sarup enclosures are rather easy to identify by their artificial features, even though most of them take advantage of natural borders like hills and waterways. The question is whether there might be locations that include remains of similar ritual activities, but with less artificial delimitation or none at all. One indication of structures connected with somewhat less imposing monumental features and setting is the timber platform of the Alvastra peat dwelling in the central part of southern Sweden (Browall 1986; Malmer 2003). Here a platform of 450 square metres, delimited by a palisade, was erected in about 3 roo BC and used in various sequences during a period of 42 years. The platform, which was divided into small cells with a centrally placed fireplace, produced a large number of finds that had been destroyed, most of them by fire.

A small number of sites not correlated to enclosures, but including a considerable number of axes and other flint artefacts, have been identified in southern Scandinavia. Two such sites, Svartskylle in the southeastern part of Scania (Larsson I989, 2000), southernmost Sweden, and Strandby (Andersen 2000:34) on the island of Funen in the south, date from the latest part of the Early Neolithic and/or the earliest part of the Middle Neolithic (figure I). Svartskylle is located in a hilly landscape about ro km from the Baltic Sea. Fragmented flint tools were found on the highest part of one of the highest hills, surrounded by wetlands. The site of Strandby is a somewhat level area close to the seashore and within a former wetland. This means that the natural setting encloses both sites.

\section{EXCAVATION AT STENSBORG}

The survey conducted at Stensborg is an excellent example of what plough-zone archaeology can contribute. The very important find as- 
semblage, combined with intensive documentation, has in itself provided information of major importance, especially concerning the relationship between southern and central Scandinavia. In view of the importance of enclosed sites of the early farming societies, delimited artificially or by natural features, the Stensborg site was a location well worth excavating in order to find out whether special features were preserved below the plough zone.

In the early I990s the eastern part of the site was included in a golf course and therefore has so far not been available for excavation. However, the slope southwest of the small ridge was excluded from the golf course.

Before the excavation a geophysical survey measuring the magnetic susceptibility was carried out. However, no obvious anomalies were registered. A survey based on phosphate testing of the area indicated no major differences. Fieldwork in 2008 was mainly intended as a test excavation. As expected, very few finds were made in the plough zone due to the collection of finds during the previous fieldwalking. The collection included just a small amount of quartz and stone waste, in contrast to an ordinary settlement where one normally finds waste in greater quantities. Only a small number of features were documented below the plough zone.

The ridge above the field included stones and boulders. But an area in the southern part turned out to be almost free of stones visible on the surface. The excavation of a few square metres proved that this was due to intentional clearing. A large amount of stone flakes as well as quartz waste together with pottery, showed that there was a settlement in this area of the same age as the finds in the field, where intensive manufacture of stone axes had been carried out.

In 2009 the excavation started with the removal of the plough zone within an area of 700 square metres in the southwestern part of the slope (figure 2). The area was chosen based on the distribution of the surface finds. One could expect that if a layer or features existed below the plough zone then the highest concentration of objects would indicate either the thickest layer or the densest presence of features or, on the contrary, the area most affected by ploughing. Therefore, the plough zone was removed within a trench with a low as well as high density of surface finds (figure 2). It turned out that most of the features were located within the eastern part of the trench, which had a low density of surface finds. The surface finds seem to indicate where the ploughing has been most destructive.

Only a small number of features could be easily identified, including a small stone paving and a couple of hearths. The paving provided 
no clue to the date or function and the hearths were from recent time. The Early Neolithic features turned out to be more difficult to identify. Most were found within an area of clay surrounded by sand. Small pits, generally less than $0.5 \mathrm{~m}$ in size and less than $0.10 \mathrm{~m}$ in depth, below the topsoil had been cut into the clay (figure 6). The pits had been filled with broken and burned artefacts. In some cases a cover of clay still existed. This meant that areas with clay had to be tested in order to recognise the features. However, in certain areas ploughing had subsequently removed the clay cover. Another and less frequent form of deposition was to dig a shallow pit in the sand and fill it with clay, in which objects were included. These features were of a somewhat larger size, measuring as much as $3 \mathrm{~m}$ across. In $20 \mathrm{II}$ the trench was enlarged to the south by removing the plough zone. Several small pits were documented within the intractable clay, most of them containing grain and a small number of broken objects.

The finds were the same as in the surface collection: fragmentary stone axes, fragments of flint axes changed by heat, sherds of pottery and lumps of burnt clay. The same features contained broken as well as burnt objects. No sherds of pottery showed any traces of heating. A small number of burnt bones were also present. Among the special finds was a small elongated stone with abrasion on one end, which was covered with red ochre (figure 5:2). A couple of pieces of volcanic tuff, of a kind found at least some $300 \mathrm{~km}$ to the north, were also recovered (Lannerbro I976:2If). These pieces, like the objects of slate, are an indicator of a wide network that not only included regions about $600 \mathrm{~km}$ to the south, represented by the flint axes, but also regions to the north.

\section{KNOWLEDGE AND KNOW-HOW IN RITUAL ACTIONS}

The flint axes were transported to the site from southernmost Scandinavia as finished or almost finished products. Since there are fragments of flint axes without polish at Stensborg, this task must in some cases have been reserved for the recipients at the final destination, while most of the polishing stones were used for the final shaping of the stone axes. There are also some finds indicating edge repair of flint axes. The knappers in central Scandinavia were experts in working stone, but this is somewhat different from knapping flint. The initial imports might have included not only objects, but also persons who could provide information about how to work this kind of flint implement. Flint is much more 


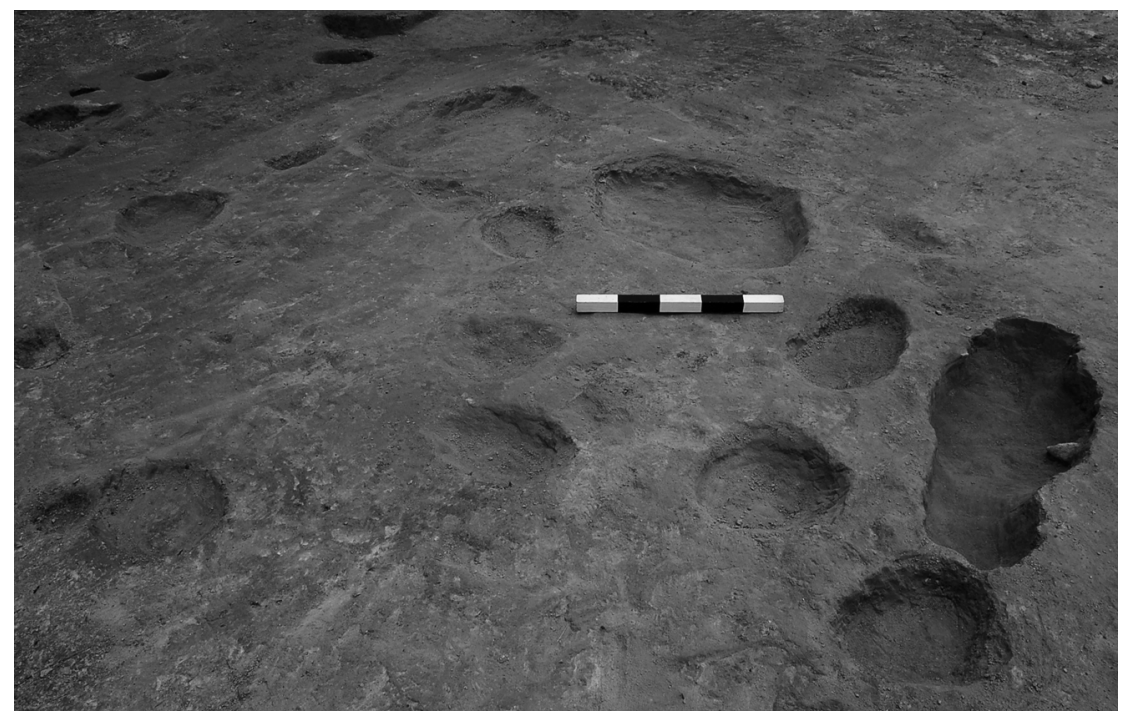

Figure 6. Two of the small pits for depositions in the clay found below the topsoil. Photo: Lars Larsson.

brittle than stone, so knowledge of how to use flint axes must have accompanied the transport of axes (Olausson 1983).

That flint axes are linked to fire could be explained by a special relationship between fire and flint. A common way to light a fire was to use flint and iron pyrite. The sparks seemed to originate from the flint, and the view that fire was incorporated within the material might have led to the acceptance of this relationship as part of the worldview. As destruction by heat was performed, this included knowledge as well as handling, a kind of know-how, of the axes related to the ritual sphere.

The transformation of flint axes involved prior heat treatment. This prior treatment was not a public pyrotechnical event with a huge fire, with the sound of flint cracking and with splinters flying out of the flames. Rather, the first stage of heat treatment was a slow and largely silent process (Larsson 200I). It might even have been conducted away from the public gaze. The subsequent result when axes were placed in fire, a slow colour change without intense cracking, may thus have been all the more remarkable for those attending the more open and public moments of particular ceremonies.

A knapper at the site who knew how flint reacted to heat might have taken the lead when flint axes were going to be transformed. In late prehistory blacksmiths were regarded as not only capable of mastering iron but also of mastering forces of the immaterial world (Østigård 2007). A similar status was accorded to the knowledge and activity of the bronze 
smelter (Goldhahn 2007). The knapping specialist who made axes might have acquired the same position. The knapper, like the axes, became positioned in a zone between the living society and another world, that of the spirits and deities. Those involved in the birth of particular axes may also have been involved in their death, transforming blades as part of the transformation of the deceased and effecting their transfer to the world of the forefathers. However, most of the stone axes had not been affected by fire. The destruction of the stone axes by destroying the edges and breaking them into pieces could have been a more public aspect of the transformation activities.

The destruction of the material culture partly by using fire most probably occurred during gatherings of people from farms across the island of Södertörn. Those gatherings may have been held for various reasons, but most likely they included mortuary rituals that involved the cremation of bodies, this being the common practice across Mälardalen at the time (Hallgren 2008:100). The evidence from the site suggests that, among other things, the process of transforming the body also involved transforming key items of material culture. The human body might in certain instances have been replaced by flint axes.

According to the interpretation of the excavated features, the objects were intentionally destroyed in rituals and then deposited in shallow pits, mixed with clay. This might be the reason why the plough zone contained so many finds. Most of the shallow pits had been destroyed or partly damaged when the slope was used as an arable field. The area has been ploughed at least since the seventeenth century. Judging from the shallow pits, the intention was not to bury the remains deep in the soil, but only to cover them with a thin layer below the surface.

Small stone chisels, mostly made from flakes with a polished edge (figure $3: 8 \& 4: 2$ ) represent the only type of stone tool that is still intact. These chisels would have been most useful for working wood. Perhaps they were used for special carvings on poles positioned on the slope (Rudebeck 20IO). A small number of postholes were documented, a couple with Early Neolithic pottery pressed down at the edge of the hole. It was not possible to identify any obvious pattern in the distribution of features.

\section{BURNT SEEDS}

An important factor that aided the identification of most pits was the presence of numerous small black dots within the fill. These were identified as burnt seeds. Small samples from three pits, two of them spaced a 
Table I. The identification of microfossils in three small pits at Stensborg.

\begin{tabular}{|c|c|c|c|c|c|c|}
\hline \multirow[t]{2}{*}{ Cultivated plants } & \multicolumn{2}{|c|}{ Pit 1} & \multicolumn{2}{|c|}{ Pit 2} & \multicolumn{2}{|c|}{ Pit 3} \\
\hline & Number & $\%$ & Number & $\%$ & Number & $\%$ \\
\hline Emmer (Triticum dicoccum) & 699,0 & 32,3 & 1305,0 & 33,6 & 426,0 & 31,5 \\
\hline Emmer glume base & 16,0 & 0,7 & 80,0 & 2,0 & 37,0 & 2,7 \\
\hline Emmer spiklet forks & 33,0 & 1,5 & 90,0 & 2,3 & 30,0 & 2,2 \\
\hline Emmer raches internodes & 1,0 & $<0,1$ & & & & \\
\hline $\begin{array}{l}\text { Emmer/Spelt wheat } \\
\text { (Triticum dicoccum/spelta) }\end{array}$ & 109,0 & 5,0 & 124,0 & 3,2 & 58,0 & 4,3 \\
\hline $\begin{array}{l}\text { cf. Spelt wheat } \\
\text { (Triticum cf. spelta) }\end{array}$ & 17,0 & 0,8 & 35,0 & 0,9 & 54,0 & 4,0 \\
\hline $\begin{array}{l}\text { Bread wheat } \\
\text { (Triticum aestivum) }\end{array}$ & 100,0 & 4,6 & 105,0 & 2,7 & 50,0 & 3,7 \\
\hline $\begin{array}{l}\text { Naked barley } \\
\text { (Hordeum vulgare var. nudu }\end{array}$ & $\begin{array}{l}66,0 \\
\text { um) }\end{array}$ & 3,1 & 61,0 & 1,6 & 13,0 & 1,0 \\
\hline cf. Naked barley & 36,0 & 1,7 & 21,0 & 0,5 & 2,0 & 0,1 \\
\hline Indefinite cerealia & 1077,0 & 49,9 & 2053,0 & 53,0 & 683,0 & 50,4 \\
\hline $\begin{array}{l}\text { Indefinite cerealia straw } \\
\text { fragment }\end{array}$ & 4,0 & 0,1 & 3,0 & 0,1 & 1,0 & 0,1 \\
\hline Total cerealia & 2158,0 & 99,7 & 3877,0 & 99,9 & 1354,0 & 100,0 \\
\hline \multicolumn{7}{|l|}{ Other plants } \\
\hline $\begin{array}{l}\text { Hazel (Corylus avellana) } \\
\text { [shell fragment] }\end{array}$ & 7,0 & 0,3 & 3,0 & $<0,1$ & & \\
\hline Total & 7,0 & 0,3 & 3,0 & $<0,1$ & & \\
\hline
\end{tabular}

couple of metres apart and a third some metres away, provided as many as about 7000 microfossils, table $\mathrm{I}$. This is the largest sample in central Sweden and probably one of the largest ever found in Scandinavia from the Early Neolithic. The sample is sufficiently large for undertaking most kinds of statistical analysis. In all three pits emmer predominates, but bread wheat, naked barley and probably spelt are also present. During the analysis some special observations were made (M. Larsson 2009). The low percentage of harvesting remains and the absence of weeds indicate that the material had been cleaned before it was burnt. The seeds are very strongly carbonized, which indicates intentional burning rather than accidental contact with fire. Another observation was the low amount of charcoal, even small particles of such. The seeds cannot have been taken directly out of an ordinary fire. Perhaps they were intentionally carbonized within some kind of container. The process of burning seeds without using charcoal needs further experiments. Burnt seeds were found in all features with burnt and broken objects, but not in 


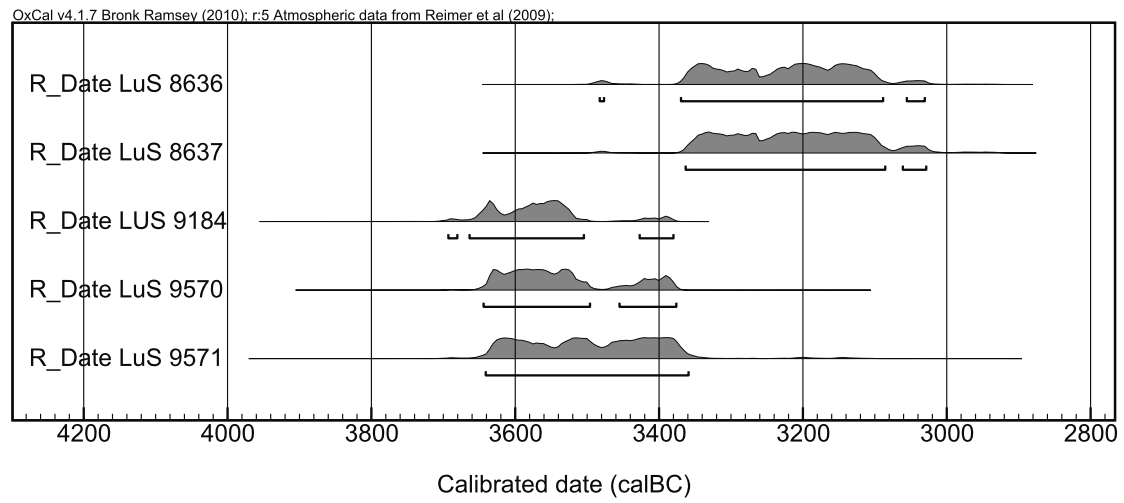

Figure 7. The presentation of calibrated radiocarbon values based on samples from seeds of emmer and spelt.

the postholes. The large number of seeds in each small analysed sample indicates that the original amount of seed must have been several litres.

The intentional destruction of objects made of rock is obvious. But usually we are not able to determine whether the depositions also included objects made of perishable materials. That burnt seeds occurred in the same pits as the objects of rock and clay, mentioned earlier, is good evidence that grain was also included in the intentional burning and subsequent deposition. The inclusion of saddle querns among the deposited objects indicates the importance of agricultural products and the objects used in processing them as part of ritual deposition.

In order to establish the relationship of the carbonized seeds to the features and other finds, five radiocarbon tests were done on seeds of emmer and spelt found in three different small pits. These gave the values $45 \mathrm{IO} \pm 50$ ( $\mathrm{LuS} 8637$ ), 45 I0 \pm 50 (LuS 8637), 4760 \pm 50 ( $\mathrm{LuS}$ 9570), $47 \mathrm{IO} \pm 75$ (LuS 957I) and 4800 $\pm 50 \mathrm{BP}(\mathrm{LuS} 9 \mathrm{I} 84)$. The values show two different intervals during a late part of the Early Neolithic (figure 7). This is somewhat puzzling as seeds from the same pit are included in both of the intervals. The compositions of all three samples are so similar that they might belong to the same collection, deposited in different pits.

\section{A PLACE FOR TRANSFORMATION}

The slope down to the beach was used for special activities with ritual purposes. By contrast, the low ridge above the slope included an area with a high quantity of refuse from stone axe production and refuse such as quartz waste, similar to that of an 'ordinary' settlement. The finds are 
of the same age as the evidence of activities on the slope. Stone axes that were cracked into pieces on the slope might have been manufactured in the settlement. A quarry for suitable raw material is located less than a kilometre away. As some of the ridge is included in a golf course, it is not possible to estimate the size of the settlement.

During the late Early Neolithic, Stensborg was located on a large island in an archipelago and close to the inner part of a small bay (figure I). The site lay close to the seashore. It had a specific setting, with a considerable depth of water just beyond the shoreline, where it would have been easy for vessels to approach. On the opposite side of the slope the ridge marked the limit of the site. On both sides, to the south and north, the site was delimited by ravines more than four metres deep with steep sides, eroded by small brooks (figure I \& 2). Thus, the field was well enclosed by natural obstacles.

From a number of excavations, mainly connected with infrastructure development, we know of fairly many settlements from the Early and Middle Neolithic on the former island (Hallgren 2008). A number of resources were available for the island settlers. The tradition of fishing and sealing could be combined with pastoralism and cereal cultivation in fertile soil.

The slope might have functioned as an assembly area where certain rituals were performed. In part, they can almost be compared to the activities conducted in connection with causewayed enclosures in southern Scandinavia. A number of exotic objects were brought to the site, such as flint axes from the south and slate objects from the north. Together with local products like stone axes and seeds, they were deliberately destroyed - or rather, the term 'transformed' might be more appropriate. The fragmentation of objects might have a special meaning, as it occurs contemporaneous to the deposition of intact artefacts. Three deposits of intact thin-butted flint axes are known in the neighbourhood of Stensborg. It is rare that burnt objects are placed in a deposit together with intact objects. If they do occur they are almost intact, which means that they were intended to be passed on to the receiver in an intact condition. The word transformation is relevant in this instance, with regard to the mass burning of objects. Here the main act was to fragment the objects. By this action the objects were transformed to another state, in which they could be accepted by the receivers. Still, the remains of these acts had to be sealed below the surface in order to keep the remains pure.

The finds and radiocarbon dates indicate that the activity might have occurred during one or a small number of gatherings.

It is of special interest to identify a relationship between the manufacture of axes at the site on the ridge and the destruction of the same 
kind of tool close by. At some causewayed enclosures of the late Early Neolithic and early Middle Neolithic waste from flint axe manufacture as well as destruction by fire has been documented. There seems to be a direct link between the birth and death of axes related to monumental enclosures (Larsson 20II).

These activities occurred during a late part of the Funnel Beaker culture of central Sweden. The culture, in its well-known south Scandinavian material composition, ends at the close of the Early Neolithic (Hallgren 2008). Later on, there are still some elements of vessel decoration and axe types that could indicate influences from the south Scandinavian Funnel Beaker culture, but pastoralism and cultivation of plants almost cease, while hunting, especially of seals, becomes more important (Malmer 2003). The Pitted Ware culture most probably evolves out of the late Early Neolithic Funnel Beaker culture. The change from Funnel Beaker culture to Pitted Ware culture is a phenomenon that has been much discussed without any one explanation gaining widespread acceptance. A natural cause, namely climatic change that resulted in serious problems for farming (Gräslund I982), has been almost neglected for the last decades in favour of factors relating to changes in social norms and attitudes that were probably established in contacts with huntergatherer societies of the east Baltic region (Edenmo et al. 1997; Carlsson 1998; Stenbäck 2003; Gill 2005; Larsson 2006). However, other studies indicate a change partly caused by ecological factors (Eriksson 2004). The intensive destruction and deposition as transformation at Stensborg might be connected with such troubling events. Valuable items were transformed into goods for divine entities in order to appease the forces that were rocking a lifestyle that had been conducted for several centuries.

Lars Larsson

Department of Archaeology and Ancient History

Box II7, SE-22 I oo Lund

Sven-Gunnar Broström Fältvägen II, SE-I 4785 Tumba

\section{Acknowledgements}

Andreas Viberg, the Archaeological Research Laboratory, Department of Archaeology and Classical Studies, Stockholm University, carried out the phosphate analyses and the geophysical prospecting. Mikael Larsson at the Institute of Archaeology and Ancient History, Lund University, made the analysis of the microfossil material. The excavation and 
research have been financed by the Berit Wallenberg Foundation, the Magn. Bergvall Foundation and the Birgit and Gad Rausing Foundation for research in the humanities. The leaders of Botkyrkas Gofklubb (the Golf Club at Botkyrka) which owns the land have been most supportive and helpful.

\section{REFERENCES}

Andersen, N. H. 1997. The Sarup Enclosures. The Funnel Beaker Culture of the Sarup Site Including two Causewayed Camps Compared to the Contemporary Settlements in the Area and Other European Enclosures. Jutland Archaeological Society Publications XXXIII:I. Aarhus.

Andersen, N.H. 2000. Kult og ritual i den ældre bondestenalder. Kuml 2000. Pp.13-57.

Carlsson, A. 1998. Tolkande arkeologi och svensk forntidshistoria. Stenåldern. Stockholm Studies in Archaeology 17. Stockholm.

Broström, S-G. I996. Inventering av stenåldersboplatser på västra Södertörn. In: Bratt, P. (Ed.). Stenålder i Stockholms län. Två Seminarier vid Stockholms läns museum. Stockholms läns museum. Pp. 66-7I. Stockholm.

Browall, H. 1986. Alvastra pålbyggnad: Social och ekonomisk bas. Theses and Papers in North-European Archaeology 8. Stockholm.

Edenmo, R., Larsson, M., Nordquist, B. \& Olsson, E. 1997. Gropkeramiker - finns de? In: Larsson, M. \& Olsson, E. (Eds). Regionalt och interregionalt. Stenåldersundersökningar I Syd- och Mellansverige. Riksantikvarieämbetet, Arkeologiska undersökningar Skrifter 23. Stockholm. Pp. I35-213.

Eriksson, G. 2004. Part Time Farmers or Hard-core Sealers? Västerbjers Studies by Means of Stable Isotope Analysis. Journal of Anthropological Archeology 23. Pp. I $35-162$.

Gill, A. 2005. Gardening Life. Reconsidering the Early Neolithic of East Central Sweden. Lund Archaeological Review 2002-2003. Pp. 23-39.

Goldhahn, J. 2007. Dödens hand - en essä om brons- och hällsmed. Gotarc Serie C Arkeologiska Skrifter No 65. Göteborg.

Gräslund, B. 1982. Climatic Fluctuations in the Early Subboreal Period. A Preliminary Discussion. In: L-K. Königsson \& Paabo, K. (Eds). Florilegium Florinis Dedicatum Striae I4. Uppsala. Pp. I3-22.

Hallgren, F., Djerw, U., af Geijerstam, M. \& Steineke, M. I997. Skogsmossen, an Early Neolithic Settlement Site and Sacrificial Fen in the Northern Border and of the Funnel-beaker Culture. Tor 29. Pp. 49-II I.

Hallgren, F. 2008. Identitet i praktiken. Lokala, regionala och överregionala sociala sammanhang inom nordisk trattbägarkultur. Coast to Coast-book I7. Uppsala.

Jensen, J. 200I. Danmarks Oldtid, Stenalder, I3000-2000 f.Kr. København.

Lannerbro, R. I976. Implements and Rockmaterial in the Prehistory of Upper Dalarna. Early Norrland 4. Stockholm.

Larsson, L. 1982. A Causewayed Enclosure and a Site with Valby Pottery at Stävie, Western Scania. Papers of the Archaeological Institute University of Lund I98II982. Pp. 65-107. 
Larsson, L. I989. Brandopfer. Der frühneolithische Fundplatz Svartskylle im südlichen Schonen, Schweden. Acta Archaeologica 59. Pp. I43-I53.

Larsson, L. 2000. The Passage of Axes: Fire Transformation of Flint Objects in the Neolithic of Southern Sweden. Antiquity 74, No. 285. Pp. 602-610.

Larsson, L. 2004. Axeheads and Fire - The Transformation of Wealth. In: Walker, E. A., Wenban-Smith, F. \& Healy, F. (Eds). Lithics in Action. Papers from the Conference Lithic Studies in the Year 2000. Lithic Studies Society Occasional Paper no. 8. Oxford. Pp. 197-205.

Larsson, L. 20Ir. The Ritual Use of Axes. In: Davis, V. \& Edmonds, M. (Eds). Stone Axe Studies III. Oxford. Pp. 203-2I4.

Larsson, M. 2006. A Tale of a Strange People. The Pitted Ware Culture in Southern Sweden. Kalmar Studies in Archaeology 2. Kalmar.

Larsson, M. 2009. Report about the Identification of Micro-fossils from Stensborg. Lund. (Unpublished report).

Malmer, M. P. 2003. The Neolithic of South Sweden. TR B, GR K, and STR. Stockholm.

Nielsen, P. O. 1978. Die Flintbeile der frühen Trichterbecherkultur in Dänemark. Acta Archaeologica 48. Pp. 6I-I38.

Olausson, D. 1983. Lithic Technological Analysis of the Thin-butted Flint Axe. Acta Archaeologica 53. Pp. I2 I-I88.

Rudebeck, E. 20IO. I trästodernas skugga - monumentala möten i neolitiseringens tid. In: Nilsson, B. \& Rudebeck, E. (Eds). Arkeologiska och förhistoriska världar. Fält, erfarenheter och stenåldersboplatser i sydvästra Skåne. Malmöfynd I9. Malmö. Pp. 83-25I.

Stenbäck, N. 2003. Människorna vid havet. Platser och keramik på ålandsöarna perioden 3500-2000 f. Kr. Stockholm Studies in Archaeology 28. Stockholm.

Taffinder, J. 1998. The Allure of the Exotic. The Social Use of Non-local Raw Materials during the Stone Age in Sweden. Aun 5. Uppsala.

Østigård, T. 2007. Transformatøren-ildens mester ijernalderen. Gotarc Serie C Arkeologiska Skrifter No 65. Göteborg. 